\title{
The Impact of Motivation for Attendance on Destination Loyalty via the Mediating Effect of Tourist Satisfaction
}

\author{
Ra'ed Masa'deh ${ }^{1}$, Mohammed Abdullah Nasseef ${ }^{2}$, Ala Alkoudary ${ }^{3}$, Hanaa Mansour ${ }^{3} \&$ Mervat Aldarabah $^{3}$ \\ ${ }^{1}$ Management Information Systems Department, School of Business, The University of Jordan, Amman, Jordan \\ 2 Department of Business Administration, Faculty of Economics and Administration, King Abdulaziz University, \\ Jeddah, Saudi Arabia \\ ${ }^{3}$ Faculty of Tourism and Hospitality Management, The University of Jordan, Aqaba, Jordan \\ Correspondence: Ra'ed Masa'deh, Management Information Systems Department, School of Business, The \\ University of Jordan, Amman, Jordan. Tel: 962-3-209-0450. E-mail: r.masadeh@ju.edu.jo
}

Received: June 4, 2017

doi:10.5430/ijba.v8n4p34
Accepted: June 20, 2017

Online Published: June 27, 2017

\begin{abstract}
The aim of this research is to explore the associations among motivation for attendance to Aqaba city, destination satisfaction, and destination loyalty. The research surveyed samples of 200 and used Structural Equation Model for research analysis and testing. The results show that motivation for attendance to Aqaba city positively affects tourists' destination loyalty. The motivation for attendance positively affects destination satisfaction; and tourists' destination satisfaction affects tourists' destination loyalty. Furthermore, the coefficient of determination $\left(\mathrm{R}^{2}\right)$ for the research endogenous variables for tourists' destination satisfaction, and tourists' destination loyalty were 0.46 , and 0.66 respectively, which indicates that the model does moderately account for the variation of the proposed model; however, opens the gate for further research.
\end{abstract}

Keywords: motivation for attendance, tourist satisfaction, destination loyalty, Aqaba, Jordan, SEM, structural equation modeling

\section{Introduction}

People travel to fulfill initial needs satisfactorily, and as to achieve tourists' satisfaction is very important for the tourism sector, because of its effect on their future economy. Tourism industry is very much affected with the perception that tourists carry with them about destination. Perceptions are always considered in relation to expectations and the dynamic nature of tourists' perceptions calls for regular assessment (Kasavana et al., 2010). Tourists always have expectations about the level of tourist services and activities and everything related to the tourist destination (Nusair \& Kandampully, 2008). These expectations are determined in the end if the tourist is satisfied with his journey or not, tourist satisfaction is of great significance, it is a form of promotion of the country, but also contributes to increased rates of retention of tourists' patronage, loyalty and acquisition, which in turn helps in realizing economic goals such as increased number of tourists and revenues. There are many studies in research focused on travel satisfaction (Nusair et al., 2011). Baker \& Crompton (2000) believed that tourist satisfaction reflects a tourist's feelings and state of mind after his/her experience with travel activities and interaction with the destination. Measuring tourist satisfaction is a key element used for the management of tourist destinations and tourism motivation has long been conceptualized in the literature and is central to understanding tourist behavior, the study of motivation has received a fair amount of attention since the 1960s.

Given that our country enjoys the components and characteristics of natural tourist attractors and the legacy of heritage and depth of cultural, social and geographical location singularly which led to the existence of opportunities. To attract tourists, it is necessary to study the tourist motive for the tourist who has an impact on satisfaction, in order to build a relationship between the tourist and the tourism destination and deepen the concept of loyalty among tourists (repeat visit). Tourist satisfaction is the ultimate goal all travel providers strive to achieve the success of products or services with tourists.

This study addresses the questions of whether the tourist motivation affects the loyalty to tourists or not and, does tourism motivation affect tourists satisfaction or not and, does the tourists satisfaction affect tourists loyalty. 


\section{Hypotheses Development}

In this section, we developed a theoretical model that discusses the relation between tourism motivation and loyalty, motivation and satisfaction, satisfaction and loyalty.

\subsection{Motivation and Destination Loyalty}

According to Lee \& Hsu (2013), motivation directly affects satisfaction and indirectly affects loyalty. Kim (2008), argued that push motivations are good predictors of pull motivations, which in turn are considered a good predictor of cognitive involvement. Cognitive involvement is a good predictor of both affective involvement and satisfaction. Affective involvement is a good predictor of satisfaction and also confirms the significant association of satisfaction with destination loyalty. Lee et al. (2014) stated that the environmental cues from the revitalization arouse positive emotions that lead to visitor satisfaction and loyalty and man-made facilities that aroused positive emotion and satisfaction. Baker \& Crompton (2000) mentioned that satisfaction referred to a tourist's emotional state after exposure to the opportunity. Snepenger, King, Marshall, \& Uysal (2006) argued that Iso-Ahola's theory asserts that personal escape, personal seeking, interpersonal escape, and interpersonal seeking motivate tourism and recreation; whereas tourism experiences exhibited higher levels of motivation, particularly for the personal seeking and personal escape dimensions. According to Maunier \& Camelis (2013), marketers should focus on elements leading to satisfaction and dissatisfaction, besides the traditional classification categories based on service attributes and the type of providers. Schofield \& Thompson (2007) found significant differences in motivation dimensions, satisfaction and intention to revisit the festival were found on the basis of visitor origin, gender and age. Dodd, et al. (2006) asserted that by providing readers with empirical evidence of the indirect effect of travel motivation and purpose on tourist experience and loyalty; while Prayag \& Ryan (2012) confirmed the relationship between involvement and loyalty, because involved tourists are more likely to recommend a destination to other people and revisit it.

One of travel motivation's underlying dimensions, shopping, positively affected Beijing tourists' revisit intention to Hong Kong; past experience, as measured by the number of prior visits and satisfaction, also positively influenced revisit intention (Huang \& Hsu, 2009). Wai, Shuo, Chen, \& Cheng (2015) found that while holistic examination of motives better predicts future intentions to visit, individual examination provides details that can help in understanding the interaction among different push and pull motives to visit a destination. Consequently, the current research presents the following hypothesis:

\section{H1: The motivation for attendance positively affects tourists' destination loyalty.}

\subsection{Motivation and Destination Satisfaction}

According to Som, Shirazi, Marzuki \& Jusoh (2011), it was found that foreigners who were satisfied with image factor were willing to recommend Penang to others. Chen (2016), said that it remains unclear why people undertake repeated visits and what kind of characteristics attracts such visitors. Al-haj mohammad (2011) argued that repeated visitors indicated that there is a stabilizing influence of satisfaction for most destinations. Asero \& Patti (2009) confirmed that tourists' satisfaction from the tourist destination does not depend heavily on the quality of services, but rather depends on the expectations of the tourist destinations. Chi et al. (2015) found that tourist satisfaction affected by the level of education of the individuals; whereas Kim \& Brown (2012) found that new experiences, adventure experiences, and geological attractions have the potential to enhance tourists' novelty-seeking experience and influence return behavior. Additional findings indicated that visitors' previous experience with the site and length of stay were important determinants of the overall satisfaction. Further, Jamilena, García, \& Moreno (2012) asserted that repeat visitors relied primarily on their own experience in terms of expectations for their trips; while Chang \& Gibson (2011) found a connection between involvement in leisure activities and subsequent tourism behaviors. This research presents the following hypothesis:

\section{H2: The motivation for attendance positively affects tourists' satisfaction.}

\subsection{Satisfaction and Destination Loyalty}

Referring to Akhoondnejad (2016), satisfaction had the direct effect on loyalty and so did trust. Lee \& Hsu (2013) found satisfaction directly affected attendee loyalty. According to Mao \& Zhang (2012), loyalty to the tourist destination includes two dimensions: word-of-mouth (WOM) and destination attachment (DA), it is found that WOM is directly affected by destination satisfaction. Pilelienè \& Grigaliūnaite (2014) revealed that the interaction effect between tourist satisfaction and loyalty is relevant, as tourist loyalty is composited from behavioral and attitudinal loyalty, besides the moderating effect of perceived value may differ regarding these approaches. Martin, Collado, \& Bosque (2013) stated that loyalty is a tourist destination and one of the most important challenges for the destination tourist. Studies agree that tourist satisfaction is the most important factor for the loyalty of the tourist 
destination. Alegre \& Garau (2010) confirmed that the experiences of dissatisfaction lower the tourist's overall satisfaction, and that negative perceptions tied to over-commercialization, overcrowding and environmental deterioration considerably lower the visitor's intention to return to the destination. According to Ozdemir \& Çizel (2013), there were important relationships between satisfaction with all-inclusive resorts, satisfaction with destination and destination loyalty. Lee \& Burns (2007) found that a high service quality tend to have high satisfaction and activity involvement that lead to destination loyalty.

Yang, Liu, Jing, \& Li (2014) confirmed that emotional value and quality value had strong positive influences on travelers' satisfaction and loyalty in an outbound tourism setting, and that the emotional value played the greatest role. Law \& Yip (2011) stated that their study pointed out significant relationships among customer satisfaction level, loyalty, and recommendation. Hultman, Skarmeas, Oghazi, \& Beheshity (2015) found that (1) destination personality promotes tourist satisfaction, tourist-destination identification, positive word-of-mouth, and revisit intentions; (2) satisfaction encourages identification and word-of-mouth; and (3) identification enhances word-of-mouth and revisit intentions. Neal \& Gursoy (2008) found the level of satisfaction or dissatisfaction during various stages of travel affects their overall satisfaction with travel and tourism services. Nisco, Marino, \& Napolitano (2015) found that country and destination images are able to mediate the effect of tourism satisfaction on post-visit behavioral intentions. Moreover, empirical findings show that a high-quality tourism experience is able to not only affect intention to return and willingness to recommend the country as a tourism destination. Consequently, the current research presents the following hypothesis:

\section{H3: Tourists' satisfaction positively affects tourists' destination loyalty.}

\section{Research Methodology}

This section provides the methodology applied in the current study. It consists of the research model, operational definitions of the study's independent, mediating and dependent variables; research hypotheses, besides data collection tool and research population and sample.

\subsection{Research Model}

The elements of this research are established based on preceding literature, either theoretically or empirically. Indeed, this study used variables that are common in tourism management literature. Adapted from Lee \& Hsu (2014), the current research considers four attitudes towards motivation for attendance to Aqaba city (the independent variable). These dimensions are cultural experience, leisure and psychology, self-expression, and destination preference; which were measured in the research questionnaire through four, four, five, and four items respectively. Also, both variables of destination satisfaction and destination loyalty were adapted from Mao \& Zhang (2014) and measured through five items each. Figure 1 represents a model for the study that shows the relationships among the research variables.

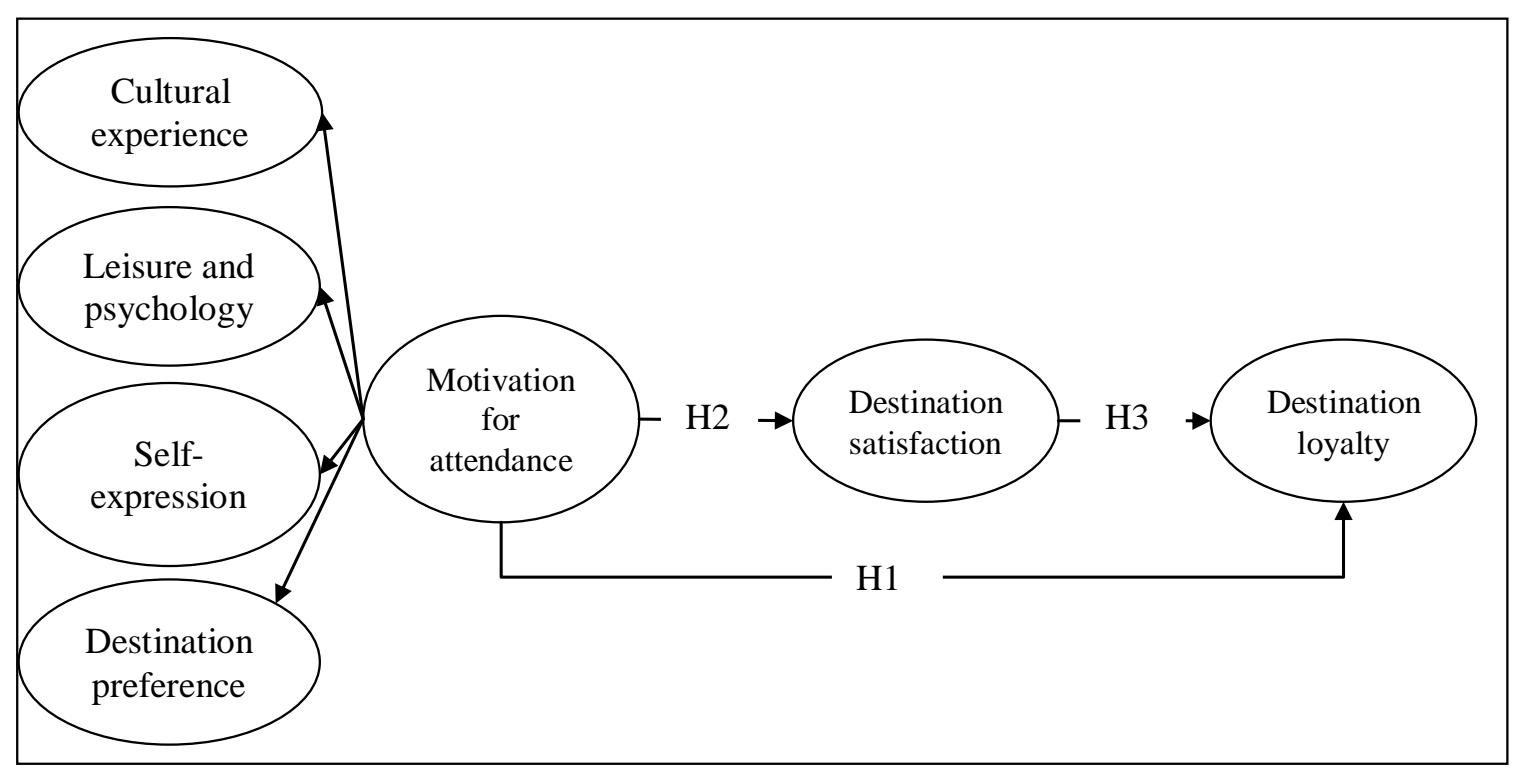

Figure 1. Research Model 


\subsection{Population and Sampling}

Empirical data for this study was collected through paper-based survey in Aqaba city in Jordan. Specifically, a survey questionnaire was used to gather data for hypotheses testing from tourists. Before implementing the surveys, the instrument was reviewed by four lecturers who are specialized in the tourism management discipline in order to identify problems with wording, content, and question ambiguity. After some changes were made based on their suggestions, the modified questionnaire was piloted on three tourists who were visiting Aqaba. Based on the feedback of this pilot study, minor edits were introduced to the survey questions, and the questionnaires were distributed to the participants. As per ethics policies, all potential participants were briefed about the nature of the work and were requested to provide explicit approval. The population of this study consists of all tourists in Aqaba located in Jordan, however, a convenience sampling technique was conducted. Further, the sample size of this study was determined based on the rules of thumb for using SEM within AMOS 21 in order to obtain reliable and valid results. Kline (2010) suggested that a sample of 200 or larger is suitable for a complicated path model. Furthermore, after eliminating the incomplete surveys, our sample size 200 from tourists met the recommended guidelines of Kline (2010), Krejcie \& Morgan (1970) and Pallant (2005). The demographic data of the respondents are reported in Table 1.

Table 1. Description of the respondents' demographic profiles

\begin{tabular}{|c|c|c|c|}
\hline Category & Category & Frequency & Percentage $\%$ \\
\hline \multirow[t]{6}{*}{ Tourist's region } & Europe & 51 & 25.5 \\
\hline & Americas & 30 & 15.0 \\
\hline & Asia & 98 & 49.0 \\
\hline & Africa & 19 & 9.5 \\
\hline & Australia & 2 & 1.0 \\
\hline & Total & 200 & 100 \\
\hline \multirow[t]{3}{*}{ Gender } & Males & 108 & 54.0 \\
\hline & Females & 92 & 46.0 \\
\hline & Total & 200 & 100 \\
\hline \multirow[t]{6}{*}{ Age } & less than 20 & 22 & 11.0 \\
\hline & 20 years - less than 25 & 54 & 27.0 \\
\hline & 25 years - less than 30 & 44 & 22.0 \\
\hline & 30 years - less than 40 & 36 & 18.0 \\
\hline & More than 40 years old & 44 & 22.0 \\
\hline & Total & 200 & 100 \\
\hline \multirow[t]{7}{*}{ Education level } & Less than high school & 22 & 11.0 \\
\hline & High school & 47 & 23.5 \\
\hline & Diploma & 42 & 21.0 \\
\hline & Bachelor & 64 & 32.0 \\
\hline & Master & 22 & 11.0 \\
\hline & Doctorate & 3 & 1.5 \\
\hline & Total & 200 & 100 \\
\hline \multirow[t]{4}{*}{ Marital status } & Unmarried & 93 & 46.5 \\
\hline & Married & 86 & 43.0 \\
\hline & Widower & 21 & 10.5 \\
\hline & Total & 200 & 100 \\
\hline
\end{tabular}

As indicated in Table 1, the demographic profile of the respondents for this study showed that they are typically males, most of them from Asia, 20 years old and above, married and married, and the majorities hold bachelor degree. 


\section{Data Analysis and Results}

In order to explore the associations among motivation for attendance to Aqaba city, destination satisfaction, and destination loyalty, in which these variables have been measured using 5-points Likert scale that varies between strongly disagree $=1$ and strongly agree $=5$; however, two items were reversed "DP3: I am more interested in visiting other destinations than Aqaba city"; and "DP4: I intend to visit destinations other than Aqaba city in the near future". Furthermore, reliability and validity analyses were conducted, descriptive analysis was used to describe the characteristic of sample and the respondent to the questionnaires besides the independent and dependent variables. Also, SEM analysis was employed to test the research hypotheses. Table 2 shows the measured constructs and the items measuring each construct.

Table 2. Constructs and measurement items

\begin{tabular}{ll}
\hline Construct & Measurement Items \\
\hline Cultural & CE1: I am visiting Aqaba city to learn about traditional customs. \\
& CE2: I am visiting Aqaba city to participate in the aboriginal festival. \\
& CE3: I am visiting Aqaba city to learn the aboriginal culture. \\
& CE4: I am visiting Aqaba city to experience something new. \\
\hline Leisure and & LP1: I am visiting Aqaba city to reduce work place stress. \\
Psychology (LP) & LP2: I am visiting Aqaba city to escape from the daily routine. \\
& LP3: I am visiting Aqaba city to improve physical health. \\
& LP4: I am visiting Aqaba city to enjoy leisure time here. \\
\hline Self-Expression & SE1: I am visiting Aqaba city to develop self-worth. \\
(SE) & SE2: I am visiting Aqaba city to achieve self-growth. \\
& SE3: I am visiting Aqaba city to buy the aboriginal-related products. \\
& SE4: I am visiting Aqaba city to promote aboriginal tourism. \\
& SE5: I am visiting Aqaba city to promote interpersonal relationships. \\
\hline Destination & DP1: Aqaba city was my first choice. \\
Preference (DP) & DP2: Aqaba city is more attractive than any other destinations. \\
& DP3: I am more interested in visiting other destinations than Aqaba city (Reverse question). \\
& DP4: I intend to visit destinations other than Aqaba city in the near future (Reverse question). \\
\hline Destination & DS1: I am satisfied with my trip to Aqaba city. \\
Satisfaction & DS2: Visiting Aqaba city is worthwhile. \\
(DS) & DS3: Aqaba city met my expectations. \\
& DS4: Visiting Aqaba city was a wise decision. \\
& DS5: I am pleased that I visited Aqaba city. \\
\hline Destination & DL1: I will recommend Aqaba city to others, including friends and relatives. \\
Loyalty (DL) & DL2: I will say positive things about Aqaba to others. \\
& DL3: If I travel overseas again, I will consider Aqaba city. \\
& DL4: If possible, I hope I can stay longer in Aqaba city. \\
& DL5: I don't think that I spent enough time in Aqaba city. \\
\hline
\end{tabular}

\subsection{Descriptive Analysis}

In order to describe the responses and thus the attitude of the respondents toward each question they were asked in the survey, the mean and the standard deviation were estimated. While the mean shows the central tendency of the data, the standard deviation measures the dispersion which offers an index of the spread or variability in the data (Pallant, 2005; Sekaran \& Bougie, 2013). In other words, a small standard deviation for a set of values reveals that these values are clustered closely about the mean or located close to it; a large standard deviation indicates the opposite. The level of each item was determined by the following formula: (highest point in Likert scale - lowest point in Likert scale) / the number of the levels used $=(5-1) / 5=0.80$, where 1-1.80 reflected by "very low", 
1.81-2.60 reflected by "low", 2.61-3.40 reflected by "moderate", 3.41-4.20 reflected by "high", and 4.21-5 reflected by "very high". Then the items were being ordered based on their means. Tables 3 and 4 show the results.

Table 3. Overall mean and standard deviation of the study's variables

\begin{tabular}{clcccc}
\hline $\begin{array}{c}\text { Type of } \\
\text { Variable }\end{array}$ & Variables & Mean & Standard Deviation & Level & Order \\
\hline $\begin{array}{c}\text { Independent } \\
\text { Variable }\end{array}$ & Motivation for attendance & 3.60 & 0.54 & High & \\
\hline & Cultural experience & 3.89 & 0.78 & High & 2 \\
\hline & Leisure and psychology & 4.03 & 0.73 & High & 1 \\
\hline & Self-expression & 3.60 & 0.77 & High & 3 \\
\hline $\begin{array}{c}\text { Mediating } \\
\text { Variable }\end{array}$ & Destination preference & 2.87 & 0.53 & Moderate & 4 \\
\hline $\begin{array}{c}\text { Dependent } \\
\text { Variable }\end{array}$ & Destination Satisfaction & 4.09 & 0.63 & High & \\
\hline
\end{tabular}

As presented in Table 3, data analysis results have shown that motivation for attendance to Aqaba is applied to a high level in which the mean score is 3.60. Further, leisure and psychology, cultural experience, and self-expression do exist highly and respectively, whereas destination preference is a plied moderately; besides both of destination satisfaction and destination loyalty are applied to a greater extent. Table 4 demonstrates the mean, standard deviations, level, and order scores for items to each variable.

Table 4. Mean and standard deviation of the study's variables

\begin{tabular}{lcccc}
\hline Cultural Experience & Mean & SD & Level & Order \\
\hline CE1 & 3.88 & 0.94 & High & 3 \\
\hline CE2 & 3.50 & 1.14 & High & 4 \\
\hline CE3 & 3.93 & 0.94 & High & 1 \\
\hline CE4 & 4.27 & 0.77 & Very high & Order \\
\hline Leisure and Psychology & Mean & SD & Level & 3 \\
\hline LP1 & 3.96 & 1.03 & High & 2 \\
\hline LP2 & 4.07 & 0.90 & High & 4 \\
\hline LP3 & 3.83 & 1.03 & High & 1 \\
\hline LP4 & 4.27 & 0.73 & Very high & Order \\
\hline Self-Expression & Mean & SD & Level & 5 \\
\hline SE1 & 3.48 & 0.94 & High & 1 \\
\hline SE2 & 4.49 & 0.89 & Very high & 2 \\
\hline SE3 & 3.72 & 1.01 & High & 4 \\
\hline SE4 & 3.64 & 0.99 & High & 3 \\
\hline SE5 & 3.71 & 0.92 & High & Order \\
\hline Destination Preference & Mean & SD & Level & 2 \\
\hline DP1 & 3.50 & 1.07 & High & 1 \\
\hline DP2 & 3.78 & 0.95 & High & 3 \\
\hline DP3 & 2.26 & 0.86 & Low & 4 \\
\hline DP4 & 1.96 & 0.71 & Low & Order \\
\hline Destination Satisfaction & Mean & SD & Level &
\end{tabular}




\begin{tabular}{lcccc}
\hline DS1 & 3.89 & 1.01 & High & 5 \\
\hline DS2 & 4.18 & 0.67 & High & 2 \\
\hline DS3 & 4.05 & 0.77 & High & 4 \\
\hline DS4 & 4.15 & 0.68 & High & 3 \\
\hline DS5 & 4.20 & 0.61 & High & 1 \\
\hline Destination Loyalty & Mean & SD & Level & Order \\
\hline DL1 & 4.24 & 0.71 & Very high & 1 \\
\hline DL2 & 4.23 & 0.67 & Very high & 2 \\
\hline DL3 & 3.89 & 0.82 & High & 5 \\
\hline DL4 & 4.03 & 0.84 & High & 3 \\
\hline DL5 & 3.97 & 0.91 & High & 4 \\
\hline
\end{tabular}

\subsection{Measurement Model}

Confirmatory factor analysis (CFA) was conducted to check the properties of the instrument items. Indeed, the measurement model indicates how latent variables or hypothetical constructs are assessed in terms of observed variables; and embodies the validity and reliability of the observed variables responses for the latent variables (Bagozzi \& Yi, 1988; Hair, et al., 2006). Because the initial CFA model did not provide an acceptable fit, two items (DP3, and DP4) were eliminated to obtain a better fitting measurement model. The results of the revised CFA indicated that the chi-square $\left(\mathrm{x}^{2}\right)$ value of the model was 688.921 , with 260 degrees of freedom $(\mathrm{p}<0.05)$, which implies that the measurement did not fit the data well. The other model fit indices used for this study were the $\mathrm{x}^{2} / \mathrm{df}$ $(688.921 / 260=2.64$; threshold less 3 for a serious viewpoint or less 5 for acceptable criteria), the Incremental Fit Index (IFI) of 0.92, Tucker- Lewis Index (TLI) of 0.90, Comparative Fit Index (CFI) of 0.92, the Goodness-of-Fit Index (GFI) of 0.90, the Adjusted Goodness-of-Fit Index (AGFI) of 0.98, the Normed Fit Index (NFI) of 0.93, the Root Mean Square Error of Approximation (RMSEA) of 0.069, and the Standardized Root Mean Square Residual (SRMR) of 0.056. Based on these fit indices, the measurement model appeared to fit the sample data well (Hair, et al., 2010).

Table 5 shows the factor loadings, Cronbach alpha, composite reliability, and Average Variance Extracted (AVE) for the variables. All of the indicators of the factor loadings exceeded 0.50, thus constitute evidence of convergent validity (Bagozzi \& Yi, 1988; Creswell, 2009). Indeed, while the measurement reached convergent validity at the item level because all of the factor loadings went above 0.50 , all of the composite reliability values exceeded 0.60 , demonstrating a high level of internal consistency for the latent variables. Further, the composite reliability of all constructs was found to be higher than 0.70, indicating good reliability. In addition, since each value of AVE exceeded 0.50 (Bagozzi \& Yi, 1988; Hair, et al., 2006), the convergent validity was proved.

Table 5. Properties of the final measurement model

\begin{tabular}{llllllll}
\hline $\begin{array}{l}\text { Constructs and } \\
\text { Indicators }\end{array}$ & $\begin{array}{l}\text { Std. } \\
\text { Loading }\end{array}$ & $\begin{array}{l}\text { Std. } \\
\text { Error }\end{array}$ & $\begin{array}{l}\text { Square } \\
\text { Multiple } \\
\text { Correlation }\end{array}$ & $\begin{array}{l}\text { Error } \\
\text { Variance }\end{array}$ & $\begin{array}{l}\text { Cronbach } \\
\text { Alpha }\end{array}$ & $\begin{array}{l}\text { Composite } \\
\text { Reliability }\end{array}$ & AVE \\
\hline $\begin{array}{l}\text { Cultural } \\
\text { Experience }\end{array}$ & & & & & 0.836 & 0.87 & 0.64 \\
\hline CE1 & 0.835 & $* * *$ & 0.698 & 0.266 & & & \\
\hline CE2 & 0.848 & 0.089 & 0.718 & 0.369 & & \\
\hline CE3 & 0.852 & 0.073 & 0.726 & 0.245 & & 0.82 & 0.55 \\
\hline CE4 & 0.572 & 0.069 & 0.223 & 0.464 & & \\
\hline $\begin{array}{l}\text { Leisure and } \\
\text { Psychology }\end{array}$ & & & & & & & \\
\hline LP1 & 0.791 & $* * *$ & 0.626 & 0.399 & & \\
\hline LP2 & 0.791 & 0.080 & 0.626 & 0.301 & & \\
\hline
\end{tabular}




\begin{tabular}{|c|c|c|c|c|c|c|c|}
\hline LP3 & 0.719 & 0.092 & 0.517 & 0.514 & & & \\
\hline LP4 & 0.507 & 0.067 & 0.247 & 0.404 & & & \\
\hline Self-Expression & & & & & 0.871 & 0.88 & 0.89 \\
\hline SE1 & 0.722 & $* * *$ & 0.522 & 0.425 & & & \\
\hline SE2 & 0.744 & 0.097 & 0.554 & 0.357 & & & \\
\hline SE3 & 0.744 & 0.110 & 0.554 & 0.461 & & & \\
\hline SE4 & 0.810 & 0.107 & 0.657 & 0.337 & & & \\
\hline SE5 & 0.763 & 0.100 & 0.583 & 0.357 & & & \\
\hline $\begin{array}{l}\text { Destination } \\
\text { Preference }\end{array}$ & & & & & 0.711 & 0.71 & 0.55 \\
\hline DP1 & 0.797 & **** & 0.635 & 0.419 & & & \\
\hline DP2 & 0.697 & 0.090 & 0.486 & 0.469 & & & \\
\hline $\begin{array}{l}\text { Destination } \\
\text { Satisfaction }\end{array}$ & & & & & 0.887 & 0.94 & 0.95 \\
\hline DS1 & 0.587 & $* * *$ & 0.345 & 0.670 & & & \\
\hline DS2 & 0.838 & 0.106 & 0.703 & 0.135 & & & \\
\hline DS3 & 0.877 & 0.125 & 0.769 & 0.139 & & & \\
\hline DS4 & 0.910 & 0.112 & 0.828 & 0.080 & & & \\
\hline DS5 & 0.856 & 0.098 & 0.733 & 0.102 & & & \\
\hline $\begin{array}{l}\text { Destination } \\
\text { Loyalty }\end{array}$ & & & & & 0.901 & 0.93 & 0.75 \\
\hline DL1 & 0.775 & $* * *$ & 0.600 & 0.204 & & & \\
\hline DL2 & 0.802 & 0.080 & 0.644 & 0.159 & & & \\
\hline DL3 & 0.789 & 0.099 & 0.623 & 0.257 & & & \\
\hline DL4 & 0.857 & 0.099 & 0.734 & 0.188 & & & \\
\hline DL5 & 0.817 & 0.109 & 0.668 & 0.277 & & & \\
\hline
\end{tabular}

Also, as noticed from Table 6, all of the intercorrelations between pairs of constructs were less than the square root of the AVE estimates of the two constructs, providing discriminant validity (Hair, et al., 2006). Consequently, the measurement results indicating that this study had adequate levels of convergent and discriminant validity.

Table 6. AVE and square of correlations between constructs

\begin{tabular}{lllllll}
\hline Constructs & CE & LP & SE & DP & DS & DL \\
\hline CE & 0.64 & & & & & \\
\hline LP & 0.30 & 0.55 & & & & \\
\hline SE & 0.61 & 0.49 & 0.89 & & & \\
\hline DP & 0.33 & 0.36 & 0.48 & 0.55 & & \\
\hline DS & 0.29 & 0.28 & 0.43 & 0.45 & 0.95 & \\
\hline DL & 0.33 & 0.32 & 0.50 & 0.39 & 0.72 & 0.75
\end{tabular}

Note: Diagonal elements are the average variance extracted for each of the six constructs. Off-diagonal elements are the squared correlations between constructs.

\subsection{Structural Model}

The SEM analysis revealed that the motivation for attendance to Aqaba city directly, positively, and significantly affected the tourists' destination loyalty $(\beta=0.325, \mathrm{t}=5.566, \mathrm{p}=0.000)$; thus, H1 was accepted. The motivation for attendance found to be directly and positively impacted destination satisfaction $(\beta=0.667, \mathrm{t}=12.954, \mathrm{p}=0.000)$; 
consequently, $\mathrm{H} 2$ was accepted. Also, tourists' destination satisfaction directly, positively, and significantly affected tourists' destination loyalty ( $\beta=0.608, t=10.258, p=0.000)$; thus, H3 was accepted. Furthermore, the coefficient of determination $\left(\mathrm{R}^{2}\right)$ for the research endogenous variables for tourists' destination satisfaction, and tourists' destination loyalty were 0.46 , and 0.66 respectively, which indicates that the model does moderately account for the variation of the proposed model.

\section{Discussion and Conclusions}

This study tried to determine impact of motivation for attendance on destination loyalty via the mediating effect of tourist satisfaction in Aqaba city in Jordan, by using three hypotheses. First, finding of this study found that the motivation for attendance positively affect tourists' destination loyalty, which is consistent with the findings of previous studies that have examined the relation between tourists motivation and loyalty. According to Lee \& Hsu (2013), motivation directly affects satisfaction and indirectly affects loyalty. It also agrees with the study of Kim (2008) as cognitive involvement is a good predictor of both affective involvement and satisfaction. Affective involvement is a good predictor of satisfaction and also confirms the significant association of satisfaction with destination loyalty. Chang \& Gibson (2011) found a connection between involvement in leisure activities and subsequent tourism behaviors. Dodd, et al. (2006) provided readers with empirical evidence of the indirect effect of travel motivation and purpose on tourist experience and loyalty. Prayag \& Ryan (2012) confirm the relationship between involvement and loyalty, because involved tourists are more likely to recommend a destination to other people and revisit. Huang \& Hsu (2009) confirmed that one of travel motivation's underlying dimensions, shopping, positively affected Beijing tourists' revisit intention. These studies agree on the current hypothesis, confirming the validity of the hypothesis.

Regarding the second hypothesis of this study, the results showed that the motivation for attendance found to be directly and positively impacted destination satisfaction. The result is consistent with Lee \& Hsu (2013) as motivation directly affects satisfaction; and Asero \& Patti (2009) that tourists' satisfaction from the tourist destination does not depend heavily on the quality of services, but rather depends on the expectations of the tourist destinations. Also, Chang \& Gibson (2011) found a connection between involvement in leisure activities and subsequent tourism behaviors.

For the third hypothesis, it was also acceptable, as indicated tourists 'destination satisfaction directly, positively, and significantly affected tourists' destination loyalty. This is consistent with Ozdemir \& Çizel (2013) that there were important relationships between satisfaction with all-inclusive resorts, satisfaction with destination and destination loyalty. In addition, Martin, Collado, \& Bosque (2013) confirmed that loyalty is a tourist destination and one of the most important challenges for the destination tourist. Indeed, several studies agreed that tourist satisfaction is the most important factor for the loyalty of the tourist destination. Al-haj mohammad (2011) found that repeat visitors indicate that there is a stabilizing influence of satisfaction for most destinations. Som, Shirazi, Marzuki \& Jusoh (2011) stated that foreigners who were satisfied with image factor were willing to recommend to others. Akhoondnejad (2016) indicated that satisfaction had the direct effect on loyalty and so did trust. Lee \& Hsu (2013) showed that satisfaction directly affects attendee loyalty, and this agrees with the study by Mao \& Zhang (2012). Pilelienè \& Grigaliūnaite (2014) stated that the interaction effect between tourist satisfaction and loyalty is relevant. Martin, Collado, \& Bosque (2013) asserted that tourist satisfaction is the most important factor for the loyalty of the tourist destination. Consequently, the result of the third hypothesis was acceptable.

This study examined the causal relationships between the motivation for attendance, satisfaction and loyalty among tourists at Aqaba city, however, has some limitations that are well taken into consideration in future studies. First, this study focused on tourists in the Aqaba city only. As to overcome this limitation, future studies should applied to Jordan as a whole as will give better and accurate results. Next, the questionnaire was distributed to tourists within a short period. Because of time constraints, which were one of limitations, therefore we recommend in future studies, taking into consideration distribution of the questionnaire should take his sufficient time to achieve the best result. We also recommend that researchers should use in future studies more than one way to collect information from tourists, and to increase the sample size for better results and more accurate statistical analysis.

Moreover, the current analytical results revealed motivation for attendance to Aqaba city do exist highly. Although leisure and psychology, cultural experiences, and self-expression are applied to a high degree; destination preferences is applied to a moderate level. Consequently, further research should take into consideration causes and explanations to such findings. Additionally, some variables that the present study has not discussed, such as the involvement in activities, quality services, may affect loyalty in tourism. Thus could consider for future research. As a tourism destination, Aqaba city has advantages such as appropriateness for family holidays, food and beverage 
services, historic sites, cultural values, nature, accommodation services and hospitality of the population. For future marketing efforts of the Aqaba city, these attributes should be specially studied and used in marketing strategies both for short-term and long-term.

Furthermore, according to Crompton (1979), understanding tourist motivation is a very critical issue to travel marketers and market segmentations. In general, tourists may have varying motivations for visiting particular destinations and may also have different satisfaction levels and standards, tourist satisfaction is closely associated with destination's long term economic success. As tourism is increasingly becoming an important sector in Jordan's economy to achieve the sustainable development of tourism, the responsible parties concerned with the tourism sector must be considered, whether formal or informal (Ministry of Tourism, hotels, restaurants, spas, resorts, etc.), to understand the importance of tourist satisfaction and that affects his/her loyalty, especially in the emerging economies such as Jordan, where the tourism sector is an important contributor to and supporter of irreplaceable for the economy in Jordan.

The study of the behavior of tourists and to know the degree of satisfaction with the tourist destination is of great importance may help to know the strengths of the destination tourism and developing them for the better, and also know the weaknesses to work on improving, and we hope the officials from the tourism sector taking these words. Also, this study can be seen as practical implications for tourism stakeholders and academicians as well. This study can be considered as a useful information and guidance for tourism related decisions. In other words, the results are of value for government officials, academicians and tourism professionals.

Also, tourism organisations strongly depend on the strategically right employment of information systems and their knowledge-based applications. Indeed, several researchers consider the information systems and in particular the information technology (IT) and its flexibility as an enabler to achieve the desired competitive advantages, and as a crucial support to operational and strategic business decisions (Al Azmi, et al., 2012; Alenezi, et al., 2015; Alkalha, et al., 2012; Almajali \& Tarhini, 2016; Altamony et al., 2012; Kateb, et al., 2015; Maqableh \& Karajeh, 2014a, 2014b; Masa'deh, 2012, 2013a, 2013b; Masa'deh, et al., 2016; Obeidat, et al., 2013; Shannak, et al., 2010, 2012a, 2012b; Tarhini et al., 2016; Vratskikh, et al., 2016); thus further research is required to examine the role of such IT applications in enhancing the managerial decisions. In addition, scholars (e.g. Masa'deh, et al. 2008; Hunaiti, et al., 2009; Masa'deh \& Kuk, 2009; Alshurideh, et al., 2012; Hajir, et al., 2015; Kannan \& Gharibeh, 2013; Masa'deh \& Shannak, 2012; Masa'deh, et al. 2013; Masa'deh, et al. 2015a, 2015b, 2015c; Masa'deh, et al. 2017; Obeidat, et al., 2012, 2016; Shannak \& Alkour, 2012; Tarhini, et al., 2015a, 2015b) emphasize the need for large firms to integrate their IT systems with their KM strategies and processes in order to survive in their highly competitive business environments, which in turn could accelerate the managerial decisions as well.

\section{References}

Abbasi, M. S., Elyas, T., \& Shah, F. (2015). Impact of individualism and collectivism over the individual's technology acceptance behaviour: A multi-group analysis between Pakistan and Turkey. Journal of Enterprise Information Management, 28(6), 747-768. https://doi.org/10.1108/JEIM-12-2014-0124

Akhoondnejad, A. (2016). Tourist Loyalty to a Local Cultural Event: The Case of Turkmen Handicrafts Festival. Tourism Management, 52, 468-477. https://doi.org/10.1016/j.tourman.2015.06.027

Al Azmi, N., Al-Lozi, M., Al-Zu'bi, Z., \& Dahiyat, S. (2012). Patients Attitudes toward Service Quality and its Impact on their Satisfaction in Physical Therapy in KSA Hospitals. European Journal of Social Sciences, 34(2), 300-314.

Al- haj mohammad, B. A. (2013). The Importance Market Segmentation Understanding the Pull Motive on Intention to Revisit Jordan. Global Management Journal, 5(2), 60-68.

Al-Badi, A., \& Al-Sawaei, S. (2017). Utilizing Social Media to Encourage Domestic Tourism in Oman. International Journal of Business and Management, 12(4), 84-94. https://doi.org/10.5539/ijbm.v12n4p84

Al-Badi, A., \& Al-Kaaf, W. (2017). Financial Incentives for Adopting Cloud Computing in Higher Educational Institutions. Asian Social Science, 13(4), 162-174. https://doi.org/10.5539/ass.v13n4p162

Al-Badi, A. H., \& Al-Qayoudhi, W. S. (2014). Adoption of social networks in business: Study of users and potential users in Oman. The International Business \& Economics Research Journal (Online), 13(2), 401-415. https://doi.org/10.19030/iber.v13i2.8457

Al-Dmour, R., \& Obeidat, B. (2015). Strategic IT-Business Alignment as Managers' Explorative and Ecploitative Strategies. European Scientific Journal, 11(7), 437-457. 
Al-Dmour, H., Al-Madani, S., Alansari, I., \& Al-Dmour, R. (2016). Factors Affecting the Effectiveness of Cause-Related Marketing Campaign: Moderating Effect of Sponsor-Cause Congruence. International Journal of Marketing Studies, 8(5), 114-127. https://doi.org/10.5539/ijms.v8n5p114

Alenezi, H., Masa'deh, R. Alalwan, A., \& Al-Qirim, N. (2017). Factors Affecting e-Government Adoption in Kuwait: A Qualitative study. Electronic Journal of e-Government, 15(2), 84-102.

Alenezi, H., Tarhini, A., \& Masa'deh, R. (2015). Investigating the Strategic Relationship between Information Quality and E-Government Benefits: A Literature Review. International Review of Social Sciences and Humanities, 9(1), 33-50.

Alkalha, Z., Al-Zu'bi, Z., Al-Dmour, H., \& Alshurideh, M. (2012). Investigating the Effects of Human Resource Policies on Organizational Performance: An Empirical Study on Commercial Banks Operating in Jordan. European Journal of Economics, Finance and Administrative Sciences, 51, 44-64.

Almajali, D., \& Tarhini, A. (2016). Antecedents of ERP Systems Implementation Success: A Study on Jordanian Healthcare Sector. Journal of Enterprise Information Management, 29(4), 549-565. https://doi.org/10.1108/JEIM-03-2015-0024

Allam, M., \& Elyas, T. (2016). Perceptions of Using Social Media as an ELT Tool among EFL Teachers in the Saudi Context. English Language Teaching, 9(7), 1-9. https://doi.org/10.5539/elt.v9n7p1

Al-Mukhaini, E. M., Al-Qayoudhi, W. S., \& Al-Badi, A. H. (2014). Adoption of social networking in education: A study of the use of social networks by higher education students in Oman. Journal of International Education Research, 10(2), 143-155. https://doi.org/10.19030/jier.v10i2.8516

Al-Qirim, M., Rouibah, K., Serhani, M. A., Yammahi, A. R., \& Yammahi, M. A. (2017). Towards a Personality Understanding of Information Technology Students and their IT Learning in UAE University. Education and Information Technologies, 1-12. https://doi.org/10.1007/s10639-017-9578-1

Al-Qirim, N., Rouibah, K., Serhani, M. A., Yammahi, A. R., \& Yammahi, M. A. (2017). Learning Orientations of IT Higher Education Students in UAE University. Education and Information Technologies, 1-14. https://doi.org/10.1007/s10639-017-9589-y

Al-Qirim N., Tarhini, A., Rouibah, K. (2017). Determinants of Big Data Adoption and Success. In International Conference on Communications and Future Internet (ICCFI 2017). Jeju Island, South Korea, 10-13 August.

Alqahtani, M. A., Al-Badi, A. H., \& Mayhew, P. J. (2012). The Enablers and Disablers of E-Commerce: Consumers' Perspectives. The Electronic Journal of Information Systems in Developing Countries, 54(1), 1-25.

Alrowwad, A., Obeidat, B.Y., \& Aqqad, N. (2017). The impact of transformational leadership on organizational performance via the mediating role of corporate social responsibility: A structural equation modeling approach. International Business Research, 10(1), 199-221. https://doi.org/10.5539/ibr.v10n1p199

Alshurideh, M., \& Alkurdi, B. (2012). The Effect of Customer Satisfaction on Customer Retention in the Jordanian Mobile Market: An Empirical Investigation. European Journal of Economics, Finance and Administrative Sciences, 47, 69-78.

Altamony, H., Alshurideh, M., \& Obeidat, B. (2012). Information Systems for Competitive Advantage: Implementation of an Organizational Strategic Management Process. Proceedings of the 18th IBIMA Conference on Innovation and Sustainable Economic Competitive Advantage: From Regional Development to World Economic, Istanbul, Turkey, 9th-10th May.

Altamony, H., Al-Salti, Z., Gharaibeh, A., \& Elyas, T. (2016). The relationship between Change Management Strategy and Successful Enterprise Resource Planning (ERP) Implementations: A Theoretical Perspective. International Journal of Business Management and Economic Research, 7(4), 690-703.

Asero, V., \& Patti, S. (2009). Asymmetric Information Tourist Satisfaction and Quality in Tourism. Annals of the University of Petroşani, Economics, 9(3).

Bagozzi, R., \& Yi, Y. (1988). On the Evaluation of Structural Evaluation Models. Journal of the Academy of Marketing Science, 16(1), 74-94. https://doi.org/10.1007/BF02723327

Baker, D., A., \& Crompton, J. L. (2000). Quality, Satisfaction and Behavior intentions. Annals of Tourism Research, 27(3), 785-804. https://doi.org/10.1016/S0160-7383(99)00108-5

Bisharat, H., Obeidat, B.Y., Alrowwad, A., Tarhini, A., \& Mukattash, I. (2017). The Effect of Human Resource Management Practices on Organizational Commitment in Chain Pharmacies in Jordan. International Journal of Business and Management, 12(1), 50-67. https://doi.org/10.5539/ijbm.v12n1p50 
Chang, S., \& Gibson, H. J. (2011). Physically Active Leisure and Tourism Connection: Leisure Involvement and Choice of Tourism Activities among Paddlers. Leisure Sciences, 33(2), 162-181. https://doi.org/10.1080/01490400.2011.550233

Chen, F. (2016). Exploring Luo-dong Home Stay and Tourist Satisfaction. International Journal Organizational Innovation, 8(3), 271-281.

Chi Lu., C. Lun. Hsu, Y., i Lu., Y., \& Ji Lin, W. (2015). Measuring Tourist Satisfaction by Motivation Travel Behavior and Shopping Behavior and Shopping Behavior: The Case of Lake Scenic Area in Taiwan. International Journal of Organizational Innovation, 8(1), 117-132.

Creswell, J. (2009). Research Design: Qualitative, Quantitative, and Mixed Methods Approaches (3rd ed.). Thousand Oaks: Sage Publications.

Cromptn, J. (1979). Motivations of Pleasure Vacations. Annals of Tourism Research, 6(4), 408-424. https://doi.org/10.1016/0160-7383(79)90004-5

Dodd, T., Yuan, J., Adams, C., \& Kolyesnikova, N. (2006). Motivations of Young People for Visiting Wine Festivals. Event Management, 10(1), 23-33. https://doi.org/10.3727/152599506779364660

El-Masri, M., \& Tarhini, A. (2015). A Design Science Approach to Gamify Education: From Games to Platforms. Twenty-Third European Conference on Information Systems (ECIS), Münster, Germany. 26-29 May 2015.

El-Masri, M., \& Tarhini, A. (2017). Factors affecting the adoption of e-learning systems in Qatar and USA: Extending the Unified Theory of Acceptance and Use of Technology 2 (UTAUT2). Educational Technology Research and Development, 65(3), 743-763. https://doi.org/10.1007/s11423-016-9508-8

El-Masri, M., Orozco, J., Tarhini, A., \& Tarhini, T. (2015). The Impact of IS-Business Alignment Practices on Organizational Choice of IS-Business Alignment Strategies. The 19th Pacific Asia Conference on Information Systems (PACIS 2015), Paper 215, Singapore, 6-9 July 2015.

Elyas, T. \& Picard, P. (2012). Teaching and Moral Tradition in Saudi Arabia: A Paradigm of Struggle or Pathway towards Globalization?. Procedia - Social and Behavioral Sciences, 41, 1083-1086. https://doi.org/10.1016/j.sbspro.2012.06.782

Fedai, L., Daglı, G., Altınay, Z., \& Altınay, F. (2017). The examination of occupational burnout and job satisfaction of the physical education teachers. International Journal of Economic Perspectives, 11(1), 12-26.

Hair, J., Black, W., Babin, B., Anderson, R., \& Tatham, R. (2006). Multivariate Data Analysis (6th ed.). New Jersey: Prentice-Hall.

Hair, J., Black, W., Babin, B., Anderson, R., \& Tatham, R. (2010). Multivariate Data Analysis (7th ed.). New Jersey: Prentice-Hall.

Hajir, J., Obeidat, B., \& Al-dalahmeh, M. (2015). The Role of Knowledge Management Infrastructure in Enhancing Innovation at Mobile Telecommunication Companies in Jordan. European Journal of Social Sciences, 50(3), 313-330.

Hamoud, M., Akour, M. A., \& Al-Salti, Z. (2016). Developing the Main Knowledge Management Process via Social Media in the IT Organisations: A Conceptual Perspective. International Journal of Business Administration, 7(5), 49-64.

Hassouna, M., Elyas, T., \& Abou Trab, M. S. (2015). Customer Churn in Mobile Markets: A Comparison of Techniques. International Business Research, 8(6), 224-237. https://doi.org/10.5539/ibr.v8n6p224

Hussian, A., Elyas, T., \& Nasseef, O. (2013). Research Paradigms: A Slippery Slope for Fresh Researchers. Life Science Journal, 10(4), 2374-2381.

Huang, S., \& Hsu, C. H. C. (2009). Effects of Travel Motivation, Past Experience, Perceived Constraint, and Attitude on Revisit Intention. Journal of Travel Research, 48(1), 29-44. https://doi.org/10.1177/0047287508328793

Hultman, M., Skarmeas, D., Oghazi, P., \& Beheshity, H. (2015). Achieving Tourist Loyalty through Destination Personality, Satisfaction, and Identification. Journal of Business Research, 68(11), 2227-2231.

Hunaiti, Z., Mansour, M., \& Al-Nawafleh. (2009). Electronic Commerce Adoption Barriers in Small and Medium-Sized Enterprises (SMEs) in Developing Countries: The Case of Libya. IBIMA Business Review, 2(5), $37-45$.

Jamilena, F., García, S., López, L., \& Moreno, L. (2102). Determinants of Satisfaction with Holidays and Hospitality 
in Rural Tourism in Spain: The Moderating Effect of Tourists' Previous Experience. Cornell Hospitality Quarterly, 54(3), 294-307. https://doi.org/10.1177/1938965512466587

Kanaan, R., \& Gharibeh, A. (2013). The Impact of Knowledge Sharing Enablers on Knowledge Sharing Capability: An Empirical Study on Jordanian Telecommunication Firms. European Scientific Journal, 9(22), 237-258.

Kateb, M., Swies, R., Obeidat, B., \& Maqableh, M. (2015). An Investigation on the Critical Factors of Information System Implementation in Jordanian Information Technology Companies. European Journal of Business and Management, 7(36), 11-28.

Kim, A., \& Brown, G. (2012). Understanding the Relationships between Perceived Travel Experiences, Overall Satisfaction, and Destination Loyalty. International Journal of Tourism and Hospitality Research, 23(3), 328-347. https://doi.org/10.1080/13032917.2012.696272

Kim, K. (2008). Analysis of Structural Equation Model for The Student Pleasure Travel Market: Motivation Involvement ,Satisfaction, and Destination Loyalty. Journal of Travel \& Tourism Marketing, 24(4), 297-313.

Kline, R. (2010). Principles and Practice of Structural Equation Modeling. The Guilford Press.

Krejcie, R., \& Morgan, D. (1970). Determining Sample Size for Research Activities. Educational and Psychological Measurement, 30, 607-610. https://doi.org/10.1177/001316447003000308

Law, R., \& Yip, R. (2011). A Study of Satisfaction Level of Hong Kong Tourists with Hot Springs Hotels and Resorts in Guangdong, China. Hospitality Review, 28(1), 83-107.

Lee, J., Graefe, A.R., \& Burns, R.C. (2007). Examining the Antecedents of Destination Loyalty in a Forest Setting. Leisure Sciences, 29, 463-481. https://doi.org/10.1080/01490400701544634

Lee, T., \& Hsu, F. (2013). Examining How Attending Motivation and Satisfaction Affects the Loyalty for Attendees at Aboriginal Festivals. International Journal of Tourism Research, 15, 18-34.

Lee, Y., Lee, K., Choi, S., Yoon, J., \& Hart, R. (2014). Tourism's Role in Urban Regeneration: Examining the Impact of Environmental Cues on Emotion, Satisfaction, Loyalty, and Support for Seoul's Revitalized Cheonggyecheon Stream District. Journal of Sustainable Tourism, 22(5), 726-749. https://doi.org/10.1080/09669582.2013.871018

Mahadeen, B., Al-Dmour, R., \& Obeidat, B. Y. (2016). Examining the effect of the Organization's Internal Control System on Organizational Effectiveness: A Jordanian empirical study. International Journal of Business Administration, 7(6), 22-41. https://doi.org/10.5430/ijba.v7n6p22

Mao, I., \& Zhang, H. (2014). Structural Relationships among Destination Preference, Satisfaction and Loyalty in Chinese Tourists to Australia. International Journal of Tourism Research, 16, 201-208.

Maqableh, M., \& Karajeh, H. (2014a). Job Scheduling for Cloud Computing Using Neural Networks. Communications and Network, 6(3), 191. https://doi.org/10.4236/cn.2014.63021

Maqableh, M., \& Karajeh, H. (2014b). A Theoretical Perspective on the Relationship between Leadership Development, Knowledge Management Capability, and Firm Performance. Asian Social Science, 10(6), 128.

Martin, H. Collado, J., \& Bosque, I. (2013). An Exploration of the Effects of Past Experience and Tourist Involvement on Destination Loyalty Formation. Current Issues in Tourism, 16(4), 331-342. https://doi.org/10.1080/13683500.2012.695773

Masa'deh, R. (2013). The Impact of Information Technology Infrastructure Flexibility on Firm Performance: An Empirical Study of Jordanian Public Shareholding Firms. Jordan Journal of Business Administration, 8(4), 204-224. https://doi.org/10.12816/0002054

Masa'deh, R., \& Kuk, G. (2009). Antecedents and Intermediaries between Strategic Alignment and Firm Performance. Conference of the Academy of Management Annual Meeting (AOM), Illinois, Chicago, USA.

Masa'deh, R., \& Maqableh, M. (2013). A Structural Equation Modeling Approach for Determining Antecedents and Outcomes of Students' Attitude toward Mobile Commerce Adoption. Life Science Journal, 10(4), 2321-2333.

Masa'deh, R., Gharaibeh, A., \& Karajeh, H. (2013). An Empirical Study of Antecedents and Outcomes of Knowledge Sharing Capability in Jordanian Telecommunication Firms: A Structural Equation Modeling Approach. Life Science Journal, 10(4), 2284-2296.

Masa'deh, R., Hunaiti, Z., \& Bani Yaseen, A. (2008). An Integrative Model Linking IT-Business Strategic Alignment and Firm Performance: The Mediating Role of Pursuing Innovation and Knowledge Management Strategies. Communications of the International Business Information Management Association (IBIMA) 
Journal, 2(24), 180-187.

Masa'deh, R., Tayeh, M., \& Al-Jarrah, I., (2015). Accounting vs. Market-based Measures of Firm Performance Related to Information Technology Investments. International Review of Social Sciences and Humanities, 6(5), 129-145.

Masa'deh, R. (2012). The Impact of Management Information Systems (MIS) on Quality Assurance (QA): A Case Study in Jordan. International Journal of Information, Business, and Management, 7(2), 93-110.

Masa'deh, R., \& Maqableh, M., (2017). The Impact of Knowledge Management on Job Performance in Higher Education: The Case of the University of Jordan. Journal of Enterprise Information Management, 30(2), 244-262. https://doi.org/10.1108/JEIM-09-2015-0087

Masa'deh, R., \& Shannak, R. (2012). Intermediary Effects of Knowledge Management Strategy and Learning Orientation on Strategic Alignment and Firm Performance. Research Journal of International Studies, 5(4), 112-128.

Masa'deh, R., Al-Dmour, R., \& Tarhini, A. (2015). Knowledge Management Strategies as Intermediary Variables between IT-Business Strategic Alignment and Firm Performance. European Scientific Journal, 11(7), $344-368$.

Masa'deh, R., Gharaibeh, A., \& Obeidat, O. (2015). Knowledge Sharing Capability: A Literature Review. In Fourth Scientific \& Research Conference on New Trends in Business, Management and Social Sciences, Istanbul, Turkey, 19-20 September 2015 (pp. 1-16). https://doi.org/10.2139/ssrn.2696924

Masa'deh, R., Obeidat, B., \& Tarhini, A. (2016). A Jordanian Empirical Study of the Associations among Transformational Leadership, Transactional Leadership, Knowledge Sharing, Job Performance, and Firm Performance: A Structural Equation Modelling Approach. Journal of Management Development, 35(5), 681-705. https://doi.org/10.1108/JMD-09-2015-0134

Maunier, C., \& Camelis, C. (2013). Toward an Identification of Elements Contributing to Satisfaction with the Tourism Experience. Journal of Vacation Marketing, 19(1), 19-39. https://doi.org/10.1177/1356766712468733

Neal, J., \& Gursoy, D. (2008). A Multifaceted Analysis of Tourism Satisfaction. Journal of Travel Research, 47, 53-62. https://doi.org/10.1177/0047287507312434

Nisco, A., Marino, G., \& Napolitano, M. (2015). Tourism Satisfaction Effect on General Country Image, Destination Image, and Post-Visit Intentions. Journal of Vacation Marketing, 21(4), 305-317. https://doi.org/10.1177/1356766715577502

Nassar, B., \& Arzoky, M. (2015). An Empirical Analysis of the Seasonal Patterns in Aggregate Directors' Trades. International Journal of Economics and Finance, 7(9), 59-84. https://doi.org/10.5539/ijef.v7n9p59

Obeidat, B. Y., Hashem, L., Alansari, I, \& Al-Salti, Z. (2016). The Effect of Knowledge Management Uses on Total Quality Management Practices: A Theoretical Perspective. Journal of Management and Strategy, 7(4), 18-29.

Obeidat, B., Al-Suradi, M., \& Tarhini, A. (2016). The Impact of Knowledge Management on Innovation: An Empirical Study on Jordanian Consultancy Firms. Management Research Review, 39(10), 1214-1238.

Obeidat, B., El-Rimawi, S., Maqableh, M., \& Al-Jarrah, I. (2013). Evaluating the Profitability of the Islamic Banks in Jordan. European Journal of Economics, Finance and Administrative Sciences, 56, 27-36.

Obeidat, B., Sweis, R., Zyod, D., \& Alshurideh, M. (2012). The Effect of Perceived Service Quality on Customer Loyalty in Internet Service Providers in Jordan. Journal of Management Research, 4(4), 224-242.

Obeidat, B.Y., Al-Sarayrah, S., Al-Salti, Z., \& Sweis, R. (2016). Cultural Influence on Strategic Human Resource Management Practices: A Jordanian case study. International Business Research, 9(10), 94-114. https://doi.org/10.5539/ibr.v9n10p94

Obeidat, B.Y., Tarhini, A., \& Aqqad, N. (2017). The impact of intellectual capital on innovation via the mediating role of knowledge management: A structural equation modeling approach. International Journal of Knowledge Management Studies, 8(2), 15-33.

Orozco, J., Tarhini, A., Masa'deh, R., \& Tarhini, T. (2015). A framework of IS/business alignment management practices to improve the design of IT Governance architectures. International Journal of Business and Management, 10(4), 1-12. https://doi.org/10.5539/ijbm.v10n4p1

Ozdemir, B., \& Çizel, B. (2012). Satisfaction with All-Inclusive Tourism Resorts: The Effects of Satisfaction with Destination and Destination Loyalty. International Journal of Hospitality \& Tourism, 13, 109-130. https://doi.org/10.1080/15256480.2012.669313 
Pallant, J. (2005). SPSS Survival Manual: A Step Guide to Data Analysis Using SPSS for Windows Version 12. Chicago, Illinois: Open University Press.

Pilelienè, L., \& Grigaliūnaitè, V. (2014). Interaction between Satisfaction and Loyalty of Lithuanian Rural Tourists a Moderating: Effect of Perceived Value. Management Theory and Studies for Rural Business and Infrastructure Development, 36(4), 297-936. https://doi.org/10.15544/mts.2014.087

Prayag, G., \& Ryan, C. (2012). Antecedents of Tourists' Loyalty to Mauritius: The Role and Influence of Destination Image, Place Attachment, Personal Involvement, and Satisfaction. Journal of Travel Research, 51(3), 70-82.

Schofield, P., \& Thompson, K. (2007). Visitor Motivation, Satisfaction and Behavioural Intention: The 2005 Naadam Festival, Ulaanbaatar. International Journal of Tourism Research, 9(5), 329-344.

Sekaran, U., \& Bougie, R. (2013). Research Methods for Business: A Skill-Building Approach (6th ed.). New York: Wiley.

Shannak, R., \& Akour, M. (2012). Knowledge Management Strategy Building: Literature Review, European Scientific Journal, 8(15), 143-168.

Shannak, R., Al-Zu'bi, Z., Obeidat, B., Alshurideh, M., \& Altamony, H. (2012a). A Theoretical Perspective on the Relationship between Knowledge Management Systems, Customer Knowledge Management, and Firm Competitive Advantage. European Journal of Social Sciences, 32(4), 520-532.

Shannak, R., Obeidat, B., \& Almajali, D. (2010). Information Technology Investments: A Literature Review. Proceedings of the 14th IBIMA Conference on Global Business Transformation through Innovation and Knowledge Management: An Academic Perspective, Istanbul-Turkey, 23rd-24th June, pp.1356-1368.

Shannak, R., Obeidat, B., \& Masa'deh, R. (2012b). Culture and the Implementation Process of Strategic Decisions in Jordan. Journal of Management Research, 4(4), 257-281. https://doi.org/10.5296/jmr.v4i4.2160

Snepenger, D., King, J., Marshall, E., \& Uysal, M. (2006). Modeling Iso-Ahola's Motivation Theory in the Tourism Context. Journal of Travel Research, 45, 140-149. https://doi.org/10.1177/0047287506291592

Som, P., Shirazi, S., Marzuki, A., \& Jusoh, A. (2011). A Critical Analysis of Tourist Satisfaction and Destination Loyalty. Journal of Global Management, 2(2), 178-183.

Tarhini, A., Al-Badi, A., Almajali, M., \& Alrabayaah, S. H. (2017). Factors influencing employees' Intention to use Cloud Computing. Journal of Management \& Strategy, 8(2), 47-62. https://doi.org/10.5430/jms.v8n2p47

Tarhini, A., Elyas, T., Akour, M. A., \& Al-Salti, Z. (2016). Technology, Demographic Characteristics and E-Learning Acceptance: A Conceptual Model Based on Extended Technology Acceptance Model. Higher Education Studies, 6(3), 72-89. https://doi.org/10.5539/hes.v6n3p72

Tarhini, A., El-Masri, M., Ali, M., \& Serrano, A. (2016). Extending the UTAUT model to understand the customers' acceptance and use of internet banking in Lebanon: A structural equation modeling approach. Information Technology and People, 29(4), 830-849. https://doi.org/10.1108/ITP-02-2014-0034

Tarhini, A., Arachchilage, N., \& Abbasi, M. (2015). A Critical Review of Theories and Models of Technology Adoption and Acceptance in Information System Research. International Journal of Technology Diffusion, 6(4), 58-77. https://doi.org/10.4018/IJTD.2015100104

Tarhini, A., Mgbemena, C., AbouTrab, M.S., \& Masa'deh, R. (2015). User Adoption of Online Banking in Nigeria: A Qualitative study. Journal of Internet Banking and Commerce, 20(3), 1-8.

Tarhini, A., Mohammed, A., \& Maqableh, M. (2016). Modeling Factors Affecting Student's Usage Behaviour of E-Learning Systems in Lebanon. International Journal of Business and Management, 11(2), 299-314. https://doi.org/10.5539/ijbm.v11n2p299

Vratskikh, I., Al-Lozi, M., \& Maqableh, M. (2016). The Impact of Emotional Intelligence on Job Performance via the Mediating Role of Job Satisfaction. International Journal of Business and Management, 8(2), 69-91. https://doi.org/10.5539/ijbm.v11n2p69

Wai, L., Shuo, Y., Chen, H., \& Cheng, H. (2015). Nostalgia as Travel Motivation and its Impact on Tourists' Loyalty. Journal of Business Research, 68(1), 81-86. https://doi.org/10.1016/j.jbusres.2014.05.003

Yang, Y., Liu, X., Jing, F., \& Li, J. (2014). How Perceived Value Affect Travelers' Satisfaction and Loyalty?. Social Behavior and Personality, 42(10), 1733-1744. https://doi.org/10.2224/sbp.2014.42.10.1733 